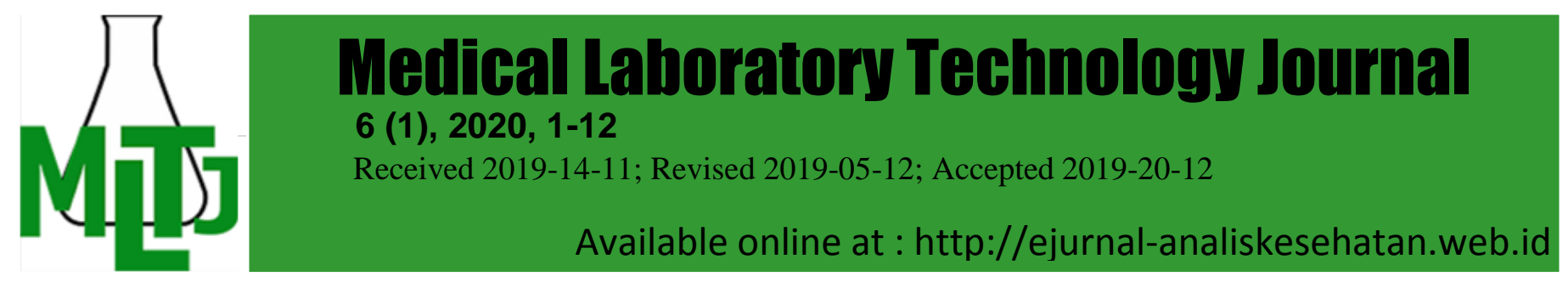

\title{
Beneficial Effects of Soygurt Intake in Type 2 Diabetes Mellitus in Animal Model Rat (Rattus Norvegitus)
}

\author{
*Ni Wayan Desi Bintari, Putu Ayu Parwati \\ Department of Medical Laboratory Technology STIKes Wira Medika Bali \\ 9A, Kecak street, Denpasar Timur District, Denpasar City 80239 Bali Province \\ Indonesia. *Email : desibintari@gmail.com \\ DOI: $10.31964 / \mathrm{mltj} . v \%$ vi\%i.258
}

\begin{abstract}
Type 2 Diabetes Mellitus (T2DM) is the more common type of diabetes results from the ineffective use of insulin. Improvement of the metabolic system in T2DM patients can be done through the regulation of gut microbiota balance. Gut microbial improvement can be modulated directly by probiotic food consumption. Soygurt is probiotic food with a low glycemic index (Gl) and glycemic load (GL) value and rich in isoflavones, which has a potential effect in reducing diabetes risk. The aim of this study is to determine the effect of soygurt consumption in blood glucose levels and body weight of albino wistar rats (Rattus norvegitus). Reseach using a completely randomized design for experimental study. Subjects of this research are 30 male rats ( $R$. norvegistus) aged 2-3 months with average body weight $150-200 \mathrm{gr}$. Diabetic rats were induced by using single intraperitoneal injection (175 mg/kg BW) alloxan monohydrate. Soygurt feeding given once daily using oral gavage feeding. The result showed that soygurt feeding in diabetic rats with three variations of treatment could significantly $(p<0,05)$, lowering blood sugar level and improve body weight after 28 days of treatment. Treatment of $4 \mathrm{ml} /$ day soygurt has the highest effect in lowering blood sugar level and improving body weight, followed by treatment of $3 \mathrm{ml} /$ day and $2 \mathrm{ml} /$ day soygurt.
\end{abstract}

Keyword: Soygurt, Type 2 Diabetes Mellitus, Blood Sugar Level, Body Weight, Rattus norvegitus

\section{INTRODUCTION}

Type 2 diabetes mellitus is a metabolic disorder characterized by hyperglycemia, which occurs due to abnormal insulin secretion, impaired insulin action, or both (Lathifah, 2013). Impaired action and resistance of insulin in type 2 diabetes mellitus are associated with the incidence of intestinal microbial dysbiosis. Dysbiosis triggers chronic systemic low-grade inflammation, which causes decreased insulin sensitivity in the liver, muscles, and adipose tissue, which leads to insulin resistance (Allin et al., 2015). The regulation of intestinal microbial balances become urgent issues in type 2 diabetes mellitus patient, especially to maintain blood sugar balance and prevent complications (Astuti \& Maulani, 2017).

Gut microbiota plays a crucial role in control fermentation and absorption of dietary polysaccharides to produce short-chain fatty acids (SCFA), modulation host immune system, modulation of inflammatory processes, extraction of energy from the host diet and alterations of human gene expression (Blandino et al., 2016). The shift of gut microbiota from normobiosis to dysbiosis will effect the deficiency of microbiota compositional and functional diversity. Dysbiosis favors the overgrowth of Gram-negative bacteria and reducing Gram-positive bacteria (Ballak et al., 2014). The overgrowth of Gram-negative bacteria will affect in increasing production of 
lipopolysaccharide (LPS) from bacteria cell walls. This condition may induce translocation of LPS and bacteria toxins across intestinal lumen into the blood circulation and triggers low-grade systemic inflammation, which plays a vital role in metabolic disorder and insulin resistance (Punder \& Pruimboom, 2015).

The abundance of gut microbial can be modulated directly through the consumption of probiotics and prebiotics (Azad et al., 2018). Probiotics are defined as living bacteria when administered in adequate amounts will confer a health benefit on the host. Probiotics products have used for centuries, especially in dairy foods such as yogurt and kefir (Ranadheera et al., 2017). Consumption of probiotics products based on cohort studies also known to be able to increase glutathione peroxidase activity and significantly reduce fasting blood sugar value, therefore suitable for people with glucose metabolic disorder (Lazar et al., 2019).

Probiotics food that began to offer as a healthy diet for T2DM is probiotic yogurt (Barengolts et al., 2019). Yogurt is fermented milk with a low glycemic index (Gl) and glycemic load (GL), which positively correlated in decreasing blood glucose (Wolever, 2017). Most commercial yogurt product is a dairy product based on cow's milk. As a cow's milk-based product, dairy yogurt may contain cholesterol based on the milk composition. Therefore the consistency of dairy yogurt in improving metabolism is still being debated (Madjd et al., 2016). Besides cow's milk, several studies state that yogurt also can be produced from vegetable milk, especially soymilk. Soymilk contains dietary fiber and relatively higher protein than cow's milk. Soymilk supplemented with lactose or glucose satisfies the requirement for lactic acid fermentation and is converted to edible yogurt-like dairy yogurt by lactic acid bacteria (Akusu \& Wordu, 2017).

Soymilk yogurt (soygurt) contains less or maybe not contain cholesterol depends on its composition. Its nutritional status can reduce the fears associated with high blood cholesterol and lactose of avid consumers of cow milk (Akusu \& Wordu, 2017). Soymilk not only high in protein but also rich in isoflavones. Isoflavones are secondary metabolites producing by the Leguminosae plant, which is an excellent nutrient for regulating and stabilizing blood glucose. Isoflavone also has been shown to reduce the risk of diabetes in a laboratory study (Dan Ramdath et al., 2017). Based on Konya et al. (2019) research, soy protein had intrinsic activity on glycemic control, and its isoflavones can improve insulin resistance and Low-Density Lipoprotein (LDL) in patients with T2DM. Nguyen et al. (2017) report that a higher intake of soymilk and major isoflavones (daidzein, genistein, and glycitein) was significantly associated with a lower risk of T2DM in Vietnamese adults. Uchitomi et al. (2019) state that genestein and daidzein in soy can positively increase betaoxidation and insulin sensitivity, which consequently decreasing fat concentration in blood and liver.

Fermented soymilk products may be beneficial from an economic than regular fermented milk products. From its nutritional point of view, soygurt contains dietary fiber and isoflavones, which can be a promising product for the T2DM diet. Some of the previous studies have reported that probiotics yogurt and soy milk consumption may reduce the risk of overweight and insulin resistance in T2DM. However, data directly relating dairy intake of soya yogurt (soygurt) to T2DM, and the effect of blood glucose and body weight remain sparse. Based on that, this study aimed to investigate the effect of daily soygurt consumption on blood glucose level and body weight in Wistar mice (Rattus norvegitus) with type 2 diabetes mellitus (T2DM). This present study also investigates the association between daily soygurt intake and lactic acid bacteria density in wistar mice with T2DM. 


\section{MATERIALS AND METHOD}

\section{Soygurt production}

Soymilk $(85 \% \mathrm{v} / \mathrm{v})$ and skim milk $(15 \% \mathrm{v} / \mathrm{v})$ pasteurized $\left( \pm 60^{\circ} \mathrm{C}\right)$ and added $1 \%$ sucrose, mixed well. After the pasteurization process, warmed milk until $\pm 40^{\circ} \mathrm{C}$ and inoculated $10 \%$ starter (Streptococcus thermophilus and Lactobacillus bulgaricus; $1: 1$ in concentration) to fermented soygurt. Incubated in room temperature for 12 hours until soygurt thick and tangi and transport to the refrigerator. Soygurt analyzed for fat, protein, and lactic acid content. Analysis conducted at the Faculty of Agricultural Technology Udayana University.

\section{Experimental animals}

Ethical approval for this study provided by the Ethical Committee of Udayana University. Subjects of this research are 30 male Albino Wistar Rat Strain (Rattus norvegistus) aged 2-3 months with average body weight 150-200 gr. Animals were housed in clear sided cages (6/cage) at controlled temperature $\left(22 \pm 2{ }^{\circ} \mathrm{C}\right)$ with an artificial 12-hr light-dark cycle and had free access to water and a standard pellet diet. Animals housed over one week acclimatization period before treatment.

\section{Diabetes induction}

Twenty four rats had fasted for 12-hours before diabetes-induced using alloxan monohydrate (Sigma Aldrich ${ }^{\mathrm{TM}}$ ) using single intraperitoneal injection (175 $\mathrm{mg} / \mathrm{kg}$ BW). Meanwhile, six rats injected with saline solution and served as a negative control group (G1). After 72 hours and 96 hours of diabetes-induced groups and negative control, groups tested for fasting blood glucose levels using Glucose meter KIT (Easy Touch GCU). Blood is collected using a syringe needle from the lateral tail vein. Diabetes type 2 induced rats have fasting blood sugar $>200 \mathrm{mg} / \mathrm{dl}$; meanwhile, normal rats have fasting blood sugar levels $<100-120 \mathrm{mg} / \mathrm{dl}$.

\section{Study design}

Reseach using Completely Randomized Design for experimental study. Experimental design using five groups, each group consists of 6 subjects. The treatment period for this study was 28 days. Diabetic rats randomly divided into four groups. Soygurt feeding given once daily at 08.00 a.m using an oral gavage needle. Each group in this study had different treatment for soygurt diet that is :

No. Group Treatment

\begin{tabular}{|c|c|c|}
\hline 1. & First Group (G1) & $\begin{array}{l}\text { Non-diabetic/ negative control group without soygurt diet } \\
\text { treatment }\end{array}$ \\
\hline 2. & Second Group (G2) & $\begin{array}{l}\text { Diabetic/ positive control group without soygurt diet } \\
\text { treatment }\end{array}$ \\
\hline 3. & Third Group (G3) & $\begin{array}{l}\text { The diabetic group with } 2 \mathrm{ml} \text { soygurt diet treatment } \\
\text { every day for } 28 \text { days }\end{array}$ \\
\hline 4. & Fourth Group (G4) & $\begin{array}{l}\text { The diabetic group with } 3 \mathrm{ml} \text { soygurt diet treatment } \\
\text { every day for } 28 \text { days }\end{array}$ \\
\hline 5. & Fifth Group (G5) & $\begin{array}{l}\text { The diabetic group with } 4 \mathrm{ml} \text { soygurt diet treatment } \\
\text { every day for } 28 \text { days }\end{array}$ \\
\hline
\end{tabular}

\section{Parameter analysis}

Every week $\left(7^{\text {th }}, 14^{\text {th }}, 21^{\text {st }}\right.$ and $28^{\text {th }}$ days), animals were tested for blood sugar level using Glucose Meter Kit (Easy Touch GCU), body weight, and lactic acid bacteria count in feces. Lactic acid bacteria counted using Standard Plate Count 
(SPC) and inoculated in MRS Agar (de Man, Rogosa, and Sharpe Agar Merck ${ }^{\mathrm{TM}}$ ) with $1 \% \mathrm{CaCO}_{3}$.

\section{Statistical Analyses}

Statistical analyses carried out using Mini Tab (Minitab Pty Ltd) Program version 19 for Windows. All data were expressed as mean \pm standard deviation, General Linear Model (GLM) ANOVA and Duncan Multiple Range Test (DMRT) to differentiate the significance of treatment of each group. $P$ value $<0,05$ were considered to be significant.

\section{RESULTS AND DISCUSSION}

\section{Type 2 Diabetes Mellitus (T2DM) Induction in Rats}

Healthy rats in acclimatization stage have normal blood sugar values in the range of $105-111 \mathrm{mg} / \mathrm{dL}$ and average body weight 167-191 gram. After induction of a single intraperitoneal dose of $175 \mathrm{mg} / \mathrm{kg}$ BW alloxan monohydrate, blood sugar in rats increases significantly than negative control treatment $(G 1)(p<0,05)$ (Table 1$)$. Alloxan induction positively causes a metabolic syndrome of T2DM in rats by increasing fasting blood glucose value in range $465-520 \mathrm{mg} / \mathrm{dL}$. Alloxan induction also affecting body weight in diabetic rats significantly $(p<0,05)$. Based on the calculation of fecal microbes, it can conclude that T2DM induction on rats did not affect lactic acid bacteria density. This happening evidenced by the lactic acid bacteria density $\left(\log _{10} \mathrm{CFU} / \mathrm{gr}\right)$ was not significantly different $(p<0,05)$ than the negative control group (G1). Lactic acid bacteria density before alloxan induction was 8,32-8,42 $\log _{10} \mathrm{CFU} / \mathrm{gr}$ in range and after treatment 8,15-8,40 $\log _{10} \mathrm{CFU} / \mathrm{gr}$ in range and were not significantly different based on the DMRT test.

Table 1. Result of Type 2 Diabetes Mellitus Induction in Rats

\begin{tabular}{|c|c|c|c|c|c|c|c|}
\hline \multirow[b]{2}{*}{ No. } & \multirow[b]{2}{*}{ Group } & \multicolumn{3}{|c|}{ Acclimatization } & \multicolumn{3}{|c|}{$\begin{array}{c}\text { After Diabetic Type } 2 \\
\text { Treatment }\end{array}$} \\
\hline & & $\begin{array}{l}\text { Blood } \\
\text { sugar } \\
\text { (mg/dl) }\end{array}$ & $\begin{array}{c}\text { Body } \\
\text { Weight } \\
\text { (gram) }\end{array}$ & $\begin{array}{c}\text { Lactid } \\
\text { Acid } \\
\text { Bacteria } \\
\left(\log _{10}\right. \\
\text { cfu/g) }\end{array}$ & $\begin{array}{l}\text { Blood } \\
\text { sugar } \\
\text { (mg/dl) }\end{array}$ & $\begin{array}{l}\text { Body } \\
\text { Weight } \\
\text { (gram) }\end{array}$ & $\begin{array}{c}\text { Lactid } \\
\text { Acid } \\
\text { Bacteria } \\
\left(\log _{10}\right. \\
\text { cfu/g) }\end{array}$ \\
\hline 1. & G1 & $\begin{array}{l}111 \pm \\
10,49^{a}\end{array}$ & $\begin{array}{r}191,667 \\
\pm 13,43^{a}\end{array}$ & $\begin{array}{l}8.34 \pm \\
0.24^{\mathrm{a}}\end{array}$ & $\begin{array}{l}103 \pm \\
11,85^{b}\end{array}$ & $\begin{array}{l}190,000 \pm \\
12,90^{\mathrm{a}}\end{array}$ & $\begin{array}{l}8.39 \pm \\
0.29^{\mathrm{a}}\end{array}$ \\
\hline 2. & G2 & $\begin{array}{l}109 \pm \\
7,66^{\mathrm{a}}\end{array}$ & $\begin{array}{l}172,500 \\
\pm 17,26^{a}\end{array}$ & $\begin{array}{l}8.42 \pm \\
0.35^{\mathrm{a}}\end{array}$ & $\begin{array}{l}520 \pm \\
35,36^{a}\end{array}$ & $\begin{array}{l}161,667 \pm \\
26,87^{\mathrm{ab}}\end{array}$ & $\begin{array}{l}8.32 \pm \\
0.32^{a}\end{array}$ \\
\hline 3. & G3 & $\begin{array}{l}106 \pm \\
13,65^{a}\end{array}$ & $\begin{array}{l}169,167 \\
\pm 18,808^{a}\end{array}$ & $\begin{array}{l}8.32 \pm \\
0.29^{a}\end{array}$ & $\begin{array}{l}497 \pm \\
52,58^{\mathrm{a}}\end{array}$ & $\begin{array}{l}146,667 \pm \\
24,94^{\mathrm{b}}\end{array}$ & $\begin{array}{l}8.24 \pm \\
0.22^{\mathrm{a}}\end{array}$ \\
\hline 4. & G4 & $\begin{array}{l}105 \pm \\
10,48^{a}\end{array}$ & $\begin{array}{l}168,333 \\
\pm 13,43^{a}\end{array}$ & $\begin{array}{l}8.35 \pm \\
0.20^{\mathrm{a}}\end{array}$ & $\begin{array}{l}470 \pm \\
74,51^{\mathrm{a}}\end{array}$ & $\begin{array}{l}146,667 \pm \\
21,14^{\mathrm{b}}\end{array}$ & $\begin{array}{l}8.15 \pm \\
0.22^{a}\end{array}$ \\
\hline 5. & G5 & $\begin{array}{l}105 \pm \\
7,67^{\mathrm{a}}\end{array}$ & $\begin{array}{l}167,500 \\
\pm 20,36^{a}\end{array}$ & $\begin{array}{l}8.33 \pm \\
0.26^{\mathrm{a}}\end{array}$ & $\begin{array}{l}465 \pm \\
52,20^{a}\end{array}$ & $\begin{array}{l}136,667 \pm \\
18,63^{b}\end{array}$ & $\begin{array}{l}8.40 \pm \\
0.32^{\mathrm{a}}\end{array}$ \\
\hline
\end{tabular}

Notes: Means that do not share a letter $(a, b, c)$ are significantly different $(p<0,05)$. G1: Negative control group (non-diabetic type 2 inducing rats). Data are mean values from six repetitions 


\section{Effect of soygurt on blood glucose level}

The blood glucose level of diabetic rats after soygurt feeding treatment with a various volume of $2 \mathrm{ml}, 3 \mathrm{ml}$, and $4 \mathrm{ml}$ is consistently decreased every week. Soygurt feeding on rats for four weeks significantly reduced blood glucose levels compared to a positive control (without soygurt feeding treatment). In the first week, G4 (3ml soygurt/ day) and G5 ( $4 \mathrm{ml}$ soygurt/day) treatment have been able to reduce blood sugar as indicated by significantly blood sugar value compared to the positive control. Meanwhile, G3 (2ml soygurt/day) treatment showed significantly different blood sugar levels in third weeks feeding compared to the positive control. After four weeks of soygurt feeding, it was known that G3 group blood sugar decrease by $40,84 \%$, G4 by $42,34 \%$, and G5 by $51,39 \%$ from 0 weeks before treatment. G5 ( $4 \mathrm{ml}$ soygurt/day) is known as the best treatment to reduce blood sugar levels in rats. In the fourth week of treatment, the blood sugar level in G5 was $226 \pm 66,94 \mathrm{mg} / \mathrm{dl}$ on average, which is almost equal compared to the healthy group (G1) group (Table 2).

Table 2. Effect of soygurt on rat's glucose level

\begin{tabular}{|c|c|c|c|c|c|}
\hline \multirow{2}{*}{ No. } & \multirow{2}{*}{ Group } & \multicolumn{4}{|c|}{ Blood Glucose (mg/dl) } \\
\hline & & 1st week & 2nd week & 3rd week & 4th week \\
\hline 1. & $\begin{array}{lr}\text { G1 } & \text { (negative } \\
\text { control/ } & \text { healthy } \\
\text { rats) } & \end{array}$ & $115 \pm 14,20^{c}$ & $95 \pm 13,55^{\mathrm{C}}$ & $103 \pm 6,52^{c}$ & $93 \pm 5,69^{c}$ \\
\hline 2. & $\begin{array}{l}\text { G2 (T2DM rats/ } \\
\text { positive control) }\end{array}$ & $542 \pm 53,75^{a}$ & $498 \pm 56,18^{a}$ & $534 \pm 39,60^{a}$ & $528 \pm 59,64^{a}$ \\
\hline 3. & $\begin{array}{l}\text { G3 (T2DM rats with } \\
2 \mathrm{ml} \text { soygurt diet) }\end{array}$ & $407 \pm 99,99^{\mathrm{ab}}$ & $362 \pm 86,72^{a b}$ & $350 \pm 119,40^{b}$ & $294 \pm 103,38^{b}$ \\
\hline 4. & $\begin{array}{l}\text { G4 (T2DM rats with } \\
3 \text { ml soygurt diet) }\end{array}$ & $361 \pm 67,08^{b}$ & $302 \pm 76,48^{b}$ & $303 \pm 65,77^{b}$ & $271 \pm 97,13^{b}$ \\
\hline 5. & $\begin{array}{l}\text { G5 (T2DM rats with } \\
4 \mathrm{ml} \text { soygurt diet) }\end{array}$ & $333 \pm 83,62^{b}$ & $285 \pm 104,94^{b}$ & $290 \pm 109,33^{b}$ & $226 \pm 66,94^{\mathrm{bc}}$ \\
\hline
\end{tabular}

Notes: Data are mean values from six repetitions. Means that do not share a letter $(a, b, c)$ are significantly different $(p<0,05)$.

\section{Effect of soygurt on body weight}

Healthy rats (G1) had normal body weight fluctuation every week. Meanwhile, rats with T2DM had drastic bodyweight loss in the first week. Rats with T2DM without soygurt supplementation (G2) in the fourth week had an average body weight of $107,500 \pm 5,59$ or decreased by $33,50 \%$ from 0 weeks after alloxan induction. Soygurt diet based on statistical analysis had a positive effect on weight improvement in rats with T2DM. After four weeks of soygurt feeding in G3, G4, and G5, the bodyweight average was significantly different from T2DM rats with a nonsoygurt diet (G2) (Table 3). Soygurt with $4 \mathrm{ml} /$ day dose known to have the best effect on increasing body weight in T2DM rats. 
Table 3. Effect of soygurt on rat's body weight

\begin{tabular}{|c|c|c|c|c|c|}
\hline \multirow[b]{2}{*}{ No. } & \multirow[b]{2}{*}{ Group } & \multicolumn{4}{|c|}{ Body Weight (gram) } \\
\hline & & 1st week & 2nd week & 3rd week & $\begin{array}{l}\text { 4th } \\
\text { week }\end{array}$ \\
\hline 1. & $\begin{array}{l}\text { G1 (negative control/ healthy } \\
\text { rats) }\end{array}$ & $\begin{array}{l}186,667 \\
\pm 13,74^{\mathrm{a}}\end{array}$ & $\begin{array}{l}186,667 \\
\pm 11,05^{\mathrm{a}}\end{array}$ & $\begin{array}{l}209,167 \\
\pm 7,31^{\mathrm{a}}\end{array}$ & $\begin{array}{l}218,333 \\
\pm 12,13^{\mathrm{a}}\end{array}$ \\
\hline 2. & $\begin{array}{l}\text { G2 (T2DM rats/ positive } \\
\text { control) }\end{array}$ & $\begin{array}{l}133,333 \\
\pm 14,62^{b}\end{array}$ & $\begin{array}{l}123,333 \\
\pm 6,87^{b}\end{array}$ & $\begin{array}{l}115,833 \\
\pm 4,48^{\mathrm{c}}\end{array}$ & $\begin{array}{l}107,500 \\
\pm 5,59^{\mathrm{c}}\end{array}$ \\
\hline 3. & $\begin{array}{l}\text { G3 (T2DM rats with } 2 \mathrm{ml} \\
\text { soygurt diet) }\end{array}$ & $\begin{array}{r}140,833 \\
\pm 20,89^{b}\end{array}$ & $\begin{array}{l}130,000 \\
\pm 20,81^{b}\end{array}$ & $\begin{array}{l}134,167 \\
\pm \\
21,291^{b c}\end{array}$ & $\begin{array}{l}145,000 \\
\pm 34,03^{b}\end{array}$ \\
\hline 4. & $\begin{array}{l}\text { G4 (T2DM rats with } 3 \mathrm{ml} \\
\text { soygurt diet) }\end{array}$ & $\begin{array}{l}140,833 \\
\pm 14,33^{b}\end{array}$ & $\begin{array}{l}131,667 \\
\pm 15,72^{b}\end{array}$ & $\begin{array}{l}138,333 \\
\pm 21,14^{\mathrm{bc}}\end{array}$ & $\begin{array}{l}149,167 \\
\pm 19,23^{b}\end{array}$ \\
\hline 5. & $\begin{array}{l}\text { G5 (T2DM rats with } 4 \mathrm{ml} \\
\text { soygurt diet) }\end{array}$ & $\begin{array}{r}137,500 \\
\pm 15,20^{b} \\
\end{array}$ & $\begin{array}{r}186,667 \\
\pm 17,26^{b} \\
\end{array}$ & $\begin{array}{l}156,667 \\
\pm 21,34^{\mathrm{b}} \\
\end{array}$ & $\begin{array}{l}156,167 \\
\pm 9,42^{b}\end{array}$ \\
\hline
\end{tabular}

Notes: Data are mean values from six repetitions. Means that do not share a letter $(a, b, c)$ are significantly different $(p<0,05)$.

\section{Effect of soygurt on lactic acid bacteria density}

In the first week after T2DM induction, there was no significant difference between lactic acid bacteria density in healthy and T2DM rats' feces. The effect of T2DM syndrome on lactic acid bacteria density appeared in the second week with a significant difference between G2 and G1 group. This result shows that the induction of T2DM has an effect on reducing lactic acid bacteria in faeses. Daily feeding of soygurt in T2DM rats based on statistical analysis is known to be able to increase lactic acid bacteria density in feces. In the second week of treatment, daily feeding of $2 \mathrm{ml}$ of soygurt (G2) was able to balance lactic acid bacteria density and was not significantly different from healthy rats (G1). Meanwhile, daily feeding of $3 \mathrm{ml}$ and 4 $\mathrm{ml}$ soygurt significantly increase lactic acid bacteria compared to $\mathrm{G} 1$ and $\mathrm{G} 2$. In the last week of treatment, daily soygurt feeding in G3, G4, and G5 were significantly increasing lactic acid bacteria density in feces of T2DM rats.

Table 4. Effect of soygurt on lactic acid bacteria density

\begin{tabular}{|c|c|c|c|c|c|}
\hline \multirow{2}{*}{ No. } & \multirow{2}{*}{ Group } & \multicolumn{4}{|c|}{ Lactic Acid Bacteria density $\left(\log _{10} \mathrm{CFU} / \mathrm{gram}\right)$} \\
\hline & & 1st week & 2nd week & 3rd week & 4th week \\
\hline 1. & G1 (negative control/ & $8.28 \pm$ & $8.57 \pm$ & $8.54 \pm$ & $8.51 \pm$ \\
\hline 2. & G2 (T2DM rats/ positive & $8.18 \pm$ & $8.04 \pm$ & $7.99 \pm$ & $8.00 \pm$ \\
\hline 3. & $\begin{array}{l}\text { G3 (T2DM rats with } 2 \mathrm{ml} \\
\text { soygurt diet) }\end{array}$ & $\begin{array}{l}8.16 \pm \\
0.32^{\mathrm{a}}\end{array}$ & $\begin{array}{l}8.65 \pm \\
0.83^{b}\end{array}$ & $\begin{array}{l}8.65 \pm \\
0.64^{b}\end{array}$ & $\begin{array}{l}9.36 \pm \\
0.23^{\mathrm{C}}\end{array}$ \\
\hline 4. & $\begin{array}{l}\text { G4 (T2DM rats with } 3 \mathrm{ml} \\
\text { soygurt diet) }\end{array}$ & $\begin{array}{l}8.15 \pm \\
0.41^{\mathrm{a}}\end{array}$ & $\begin{array}{l}9.28 \pm \\
0.44^{c}\end{array}$ & $\begin{array}{l}9.69 \pm \\
0.48^{\mathrm{c}}\end{array}$ & $\begin{array}{l}9.80 \pm \\
0.69^{c}\end{array}$ \\
\hline 5. & $\begin{array}{l}\text { G5 (T2DM rats with } 4 \mathrm{ml} \\
\text { soygurt diet) }\end{array}$ & $\begin{array}{l}8.40 \pm \\
0.32^{\mathrm{b}}\end{array}$ & $\begin{array}{l}9.46 \pm \\
0.31^{\mathrm{c}}\end{array}$ & $\begin{array}{l}9.71 \pm \\
0.15^{\mathrm{c}}\end{array}$ & $\begin{array}{l}9.70 \pm \\
0.15^{\mathrm{c}}\end{array}$ \\
\hline
\end{tabular}

Notes: Data are mean values from six repetitions. Means that do not share a letter $(a, b, c)$ are significantly different $(p<0,05)$. 


\section{Gross composition of soygurt}

The result of the gross composition of soygurt presented in Table 5. Based on data analysis, soygurt product has balance composition for protein, fat, and lactic acid.

Table 5. Composition of soygurt

\begin{tabular}{ccccc}
\hline No. & Product & Protein (\%FW) & Fat (\%FW) & $\begin{array}{c}\text { Lactic Acid } \\
(\% F W)\end{array}$ \\
\hline 1 & Soygurt & 4,1972 & 4,6636 & 4,0826 \\
\hline
\end{tabular}

Yogurt products are generally produced from cow's milk as raw material and well known as milk-based yogurt. In soygurt, cow milk is replaced by soy milk, which has a similar nutritional value and a good source of protein (Messina, 2016). Serlahwaty et al. (2015) state that end product of soygurt is usually thinner than milkbased yogurt. To make it thicker skim milk usually adds as a thickener addictive. Skim milk in soygurt fermentation can increase the total of non-fat solids, improving consistency and viscosity and coagulant formation. The result of gross composition analysis showed that soygurt contains protein $4,1972 \%$ and fat $4,6636 \%$ (Table 5) and accordance with quality requirements based on SNI 2981:2009. However, lactic acid composition in the product was not following SNI 2981:2009 and needed to evaluate. According to Mulyani et al. (2016), it can be evaluated by giving different variations of temperature and fermentation time in soygurt preparation.

Soygurt products in the present study tested to determine its benefits in blood sugar level, body weight, and lactic acid bacteria density in rat feces. The test was performed on male albino Wistar rats with T2DM positive (blood sugar $>200 \mathrm{mg} / \mathrm{dl}$ ). Induction of T2DM was carried out by inducing rats with a single intraperitoneal dose of $175 \mathrm{mg} / \mathrm{kg}$ alloxan monohydrate. Results showed that alloxan could positively cause hyperglycemia in rats with fasting blood sugar value $465-529 \mathrm{mg} / \mathrm{dl}$ and significantly different $(p<0,05)$ with negative control (G1) (Table 1). Rats after T2DM induction also experienced significant weight loss and different $(p<0,05)$ from negative control after four days of conditioning (Table 1). Based on significant fasting blood sugar values (>400 mg/dl) and significant weight loss, it can be concluded that T2DM conditioning in experimental rats has been achieved.

This present study was similar to previous findings by Utami et al. (2015) that have reported that alloxan monohydrate had a positive effect as diabetogenic in rats to perform T2DM syndrome. Research by (Husni et al., 2016) showed that the administration of alloxan in rats led to a significant increase in blood glucose levels after three days. Alloxan induced diabetic rats did not show a significant decrease in body weight after the induction. However, body weight had decreased in 15 days of treatment and significantly different from the healthy rat group. Alloxan is diabetogenic that can induce T2DM conditions in animals in a relatively short period. As a strong oxidant, alloxan can increase the generation of reactive oxygen species from metabolic reactions in the body. Together with the massive increase of cytosolic calcium concentration, it can rapidly cause the destruction of pancreatic $\beta$-cells (Susilawati et al., 2014; Ighodaro et al., 2018). Alloxan-induced diabetes in rats also can trigger liver morphological and ultrastructural changes that closely resembled human disease (Lucchesi et al., 2015).

This present study showed that soygurt feeding in diabetic rats with three variations of treatment could significantly $(p<0,05)$, lowering the blood sugar level in the third week of treatment. The best dose for lowering blood glucose levels quickly 
was $4 \mathrm{ml} /$ day (G5). Treatment of $4 \mathrm{ml} /$ day soygurt in the first week was able to lower blood glucose levels significantly compared to the diabetic control group. In 0 weeks before soygurt feeding treatment, the average blood sugar level in G5 diabetic rats was $465 \pm 52,2 \mathrm{mg} / \mathrm{dl}$, after four weeks of $4 \mathrm{ml}$ soygurt feeding blood sugar levels was $226 \pm 66,94 \mathrm{mg} / \mathrm{dl}$ (Table 2) or decreased by $51,39 \%$. Treatment of $2 \mathrm{ml}$ and $3 \mathrm{ml}$ soygurt also had a positive effect on lowering the blood sugar level in diabetic rats because it was significantly different $(p<0,05)$ from control (G2) (Table 2). This result also supports the previous study by Sartang et al. (2015) that reported the effect of probiotic soymilk fortified with Omega-3 in rats induced with Streptozotocin Nicotinamide, which significantly reduced blood sugar levels. Riyanto \& Muwarni (2015) also report that soy fermentation products can lower blood sugar and lowdensity lipoprotein (LDL) in hypercholesterolemia rats. Choi et al. (2016) also reported that soy fermentation with probiotic Licheniformis-67, significantly lowering blood sugar, insulin levels, serum, and hepatic lipid profiles.

In this study, there was a significant reduction in body weight in diabetic rats after alloxan induction. Healthy rats in the G1 group were in generally good condition and had progressive weight gain every week. In the fourth week of treatment, average body weight in $\mathrm{G} 1$ was $218,333 \pm 12,13 \mathrm{gram}$, and significantly different from diabetics rats (G2) with average bodyweight 107,500 $\pm 5,59$ gram (Table 3 ). The weight loss may be due to the catabolic processes involved in diabetes mellitus. From the first week of soygurt feeding in $2 \mathrm{ml}$ (G3), $3 \mathrm{ml}$ (G4), and $4 \mathrm{ml}$ (G5) volume, body weight in diabetic rats were significantly increased compared to non-yogurt treatment diabetic rats (G2). The result in this present study showed that daily soygurt feeding in diabetic rats could improve body weight in diabetic rats; this may be attributed to the mitigation of catabolic processes by soygurt. This present study support previous research by Veerichetty (2018), who also stated that a combination of soymilk and flaxseed milk fermentation could significantly increase body weight in diabetic rats in the first week of treatment.

In general, the result of this study support another research related to potential probiotics products, especially soygurt, as a healthy diet on T2DM. Jayaswal \& Prabhakar (2017) stated that probiotics bacteria such as Lactobacillus acidophilus and Bifidobacterium bifidum have a vital role in helping stabilize blood sugar levels. Kasińska \& Drzewoski (2015) revealed that probiotic bacteria in yogurt could help maintain intestinal microbiota. These effects inhibit the transfer of bacterial endotoxins into the bloodstream and reduce the production of a proinflammatory cytokine to reduce inflammatory response through neutralizing circulating lipopolysaccharides (LPS). Decreased inflammation will correlate in lowering insulin resistance, and blood glucose levels can be controlled. Based on the result in the present study (Table 4), daily soygurt feeding in diabetic rats significantly increased lactic acid bacteria density in feces compared to healthy rats (control group G2). Statistical analysis showed that an increase of lactic acid bacteria in feces was positively correlated with blood sugar decrease in diabetic rate, so it can be concluded that soygurt feeding was able to improve gut microbial dysbiosis due to T2DM syndrome.

Soygurt effectiveness in lowering the T2DM effect can be influenced by the high content of soy milk in the product. Soymilk, according to Bintari et al. (2015), is rich in isoflavones, which are commonly known as antihyperglycemic agents. Soy isoflavones are active biological substances with estrogen-like chemical structures. Several epidemiological types of research have associated isoflavone consumption by reducing the risk of diabetes and diabetes-related complications. Soybeans 
naturally contain isoflavones, including genistein (El-kordy \& Alshahrani, 2015), daidzein, and glycitein (Sahin et al., 2019). Genistein, as predominant natural soy isoflavone, has a protective effect on pancreatic $\beta$-cells damage, possesses the ability to regenerate $\beta$-cells, and improves serum levels of insulin and glucose in STZ-induced diabetic rats. It can be concluded that genistein in soy is an anti diabetogenic potential agent for T2DM. High dosage of genistein possesses the ability to regenerate $\beta$-cells that results in increasing the lowered serum insulin and consequently decreasing high serum glucose in diabetic rats (El-kordy \& Alshahrani, 2015).

The result of this study showed that soygurt product was effective in improving metabolism in T2DM rats in terms of their ability to lowering blood sugar levels, improving body weight, and lactic acid bacteria. The fermentation process in soygurt is an efficient way to produce bioactive peptides; it also promotes protein digestion and solubilization of calcium and improves the health and immune system (Veerichetty, 2018). Probiotic supplementation is positively correlated with gut microbiota modification, and it may be a method for preventing and control hyperglycemia in clinical practice (Wu et al., 2015).

The limitation of this study has not yet analyzed the correlation of soygurt consumption on improving gut microbiota and its effect on blood sugar levels. Further studies with similar objectives are recommended to evaluate soygurt adjunctive therapy for T2DM and its correlation in gut microbiota modification. We recognize our results in this animal model study may not powerful enough to predict the effects of soygurt in blood sugar and body weight balancing in humans with T2DM. Lastly, we recommend using a large number of animal studies and an equal number of controls to provide more statistical robustness of the effect of soygurt consumption in blood sugar and body weight balancing in T2DM syndrome.

\section{CONCLUSION}

Soygurt consumption have a positive effect on lowering blood glucose levels in rats with Type 2 Diabetes Mellitus. Daily soygurt consumption was also effective in improving the rat's body weight after 28 days of treatment.

\section{ACKNOWLEDGEMENT}

This research was supported by RISTEKDIKTI (Ministry of Research, Technology, and Higher Education of The Republic of Indonesia) Research Grant.

\section{REFERENCES}

Akusu, O., \& Wordu, G. (2017). Production and Evaluation of Composite Soymilk Yoghurt. Indian Journal of Nutrition, 4(4), 1-4. Retrieved from https://www.opensciencepublications.com/wp-content/uploads/IJN-2395-2326-4168.pdf

Allin, K. H., Nielsen, T., \& Pedersen, O. (2015). Mechanism in Endocrinology: Gut Microbiota in Patients With Type 2 Diabetes Mellitus. European Journal of Endocrinology, 172(2015), 167-177. https://doi.org/10.1530/EJE-14-0874

Astuti, A., \& Maulani, M. (2017). Pangan Indeks Glikemik Tinggi Dan Glukosa Darah Pasien Diabetes Mellitus Tipe II. Jurnal Endurance, 2(2), 225-231. https://doi.org/10.22216/jen.v2i2.1956

Azad, A. K., Sarker, M., Li, T., \& Yin, J. (2018). Probiotic Species in the Modulation of Gut Microbiota: An Overview Probiotic Species in the Modulation of Gut 
Microbiota: An Overview. Biomed Research Journal, 2018(May), 1-8. https://doi.org/10.1155/2018/9478630

Ballak, D. B., Diepen, J. A. Van, Moschen, A. R., Jansen, H. J., Hijmans, A., Kersten, S., ... Stienstra, R. (2014). IL-37 Protects Against Obesity-Induced Inflammation and Insulin Resistance. Nature Communications, 6(6039), 1-13. https://doi.org/10.1038/ncomms5711

Barengolts, E., Smith, E. D., Reutrakul, S., Tonucci, L., \& Anothaisintawee, T. (2019). The effect of probiotic yogurt on glycemic control in type 2 diabetes or obesity: A meta-analysis of nine randomized controlled trials. Nutrients, 11(3), 6-8. https://doi.org/10.3390/nu11030671

Bintari, S. H., Putrinintyas, N. D., Nugraheni, K., Widyastiti, N. S., Dharmana, E., \& Johan, A. (2015). Comparative Effect of Tempe and Soymilk on Fasting Blood Glucose, Insulin Level and Pancreatic Beta Cell Expression (Study on Streptozotocin-Induced Diabetic Rats). Pakistan Journal of Nutrition, 14(4), 239 246. Retrieved from https://scialert.net/abstract/?doi=pjn.2015.239.246

Blandino, G., Inturri, R., Lazzara, F., Rosa, M. Di, \& Malaguarnera, L. (2016). Impact of Gut Microbiota on Diabetes Mellitus. Diabetes and Metabolism, Diabet763(13), 1-13. https://doi.org/10.1016/j.diabet.2016.04.004

Choi, J. H., Pichiah, P. B. T., Kim, M. J., \& Cha, Y. S. (2016). Cheonggukjang , a Soybean Paste Fermented with B . licheniformis 67 Prevents Weight Gain and Improves Glycemic Control in High Fat Diet Induced Obese Mice. J.Clin.Biochem.Nutr, 59(1), 31-38. https://doi.org/10.3164/jcbn.15

Dan Ramdath, D., Padhi, E. M. T., Sarfaraz, S., Renwick, S., \& Duncan, A. M. (2017). Beyond the cholesterol-lowering effect of soy protein: A review of the effects of dietary soy and its constituents on risk factors for cardiovascular disease. Nutrients, 9(324), 1-24. https://doi.org/10.3390/nu9040324

El-kordy, E. A., \& Alshahrani, A. M. (2015). Effect of Genistein , a Natural Soy Isoflavone, on Pancreatic B-Cells of Streptozotocin-Induced Diabetic Rats: Histological and Immunohistochemical Study. Journal of Microscopy and Ultrastructure, 3(3), 108-119. https://doi.org/10.1016/j.jmau.2015.03.005

Husni, A., Pawestri, S., \& Isnansetyo, A. (2016). Blood Glucose Level and Lipid Profile of Alloxan-Induced Diabetic Rats Treated With NA-Alginate From Seaweed Turbinaria ornata (Turner) J. Agardh. Jurnal Teknologi, 78(4-2), 7-14. https://doi.org/10.11113/jt.v78.8145

Ighodaro, O., Adeosun, A., \& Akinloye, O. A. (2018). Alloxan-induced Diabetes , a Common Model for Evaluating the Glycemic-Control Potential of Therapeutic Compounds and Plants Extracts in Experimental studies. Medicina, 53(2017), 365-374. Retrieved from https://www.ncbi.nlm.nih.gov/pubmed/29548636

Jayaswal, R. P., \& Prabhakar, P. K. (2017). Probiotics- A new Diabetes Management Tool. International Journal of Green Pharmacy, 11(3), 395-400. Retrieved from https://pdfs.semanticscholar.org/e8ba/b728116cd809d27b51ba73ed7cc3453d2 00d.pdf

Kasińska, M. A., \& Drzewoski, J. (2015). Effectiveness of Probiotics in Type 2 Diabetes : a Meta-Analysis. Polskie Archiwum Medygyny Wewnetrznej, 125(11), 803-813. Retrieved from https://www.ncbi.nlm.nih.gov/pubmed/26431318

Konya, J., Sathyapalan, T., Kilpatrick, E. S., \& Atkin, S. L. (2019). The effects of soy protein and cocoa with or without isoflavones on glycemic control in type 2 diabetes. A double-blind, randomized, placebo-controlled study. Frontiers in Endocrinology, 10(MAY), 1-6. https://doi.org/10.3389/fendo.2019.00296 
Lathifah, N. L. (2013). Hubungan Durasi Penyakit dan Kadar Gula Darah Dengan Keluhan Subyektif Penderita Diabetes Melitus. Jurnal Berkala Epidemiologi, 5(2), 231-239. https://doi.org/10.20473/jbe.v5i2.2017.231-239

Lazar, V., Ditu, L. M., Pircalabioru, G. G., Picu, A., Petcu, L., Cucu, N., \& Chifiriuc, M. C. (2019). Gut microbiota, host organism, and diet trialogue in diabetes and obesity. Frontiers in Nutrition, 6(21), 1-20. https://doi.org/10.3389/fnut.2019.00021

Lucchesi, A. N., Cassettari, L. L., \& Spadella, C. T. (2015). Alloxan-Induced Diabetes Causes Morphological and Ultrastructural Changes in Rat Liver that Resemble the Natural History of Chronic Fatty Liver Disease in Humans. Journal of Diabetes Research, 2015, 1-12. Retrieved from https://www.hindawi.com/journals/jdr/2015/494578/

Madjd, A., Taylor, M. A., Neek, L. S., Delavari, A., Malekzadeh, R., MacDonald, I. A., \& Farshchi, H. R. (2016). Effect of weekly physical activity frequency on weight loss in healthy overweight and obese women attending a weight loss program: A randomized controlled trial. American Journal of Clinical Nutrition, 104(5), 12021208. https://doi.org/10.3945/ajcn.116.136408

Messina, M. (2016). Soy and health update: Evaluation of the clinical and epidemiologic literature. $\quad$ Nutrients, $8(12), \quad$ 1-42. https://doi.org/10.3390/nu8120754

Mulyani, S., Fajariyah, N., \& Pratiwi, W. (2016). Profil Kadar Protein, Kadar Lemak, Keasaman, Dan Organoleptik Soygurt Kulit Buah Pisang Raja (Musa textilia) Pada Variasi Suhu Dan Waktu Fermentasi. Jurnal Kimia Dan Pendidikan Kimia, 1(2), 48-57. Retrieved from https://www.google.com/search?safe $=$ strict\&sxsrf=ACYBGNR6fWrZFPp0RmEvAcxrm3SWwRyYZQ\% $\quad 3 A 157$ 0120607007\&ei=nyOWXa4Jm97Puw_4urC4Cw\&q=Profil+Kadar+Protein\%2C+ Kadar+Lemak\%2C+Keasaman\%2C+Dan+Organoleptik+Soygurt+Kulit+Buah+Pi sang+Raja+\%28Musa+textilia\%29+Pada+Vari

Nguyen, C. T., Pham, N. M., Do, V. V., Binns, C. W., Hoang, V. M., Dang, D. A., \& Lee, A. H. (2017). Soyfood and isoflavone intake and risk of type 2 diabetes in Vietnamese adults. European Journal of Clinical Nutrition, 71(10), 1186-1192. https://doi.org/10.1038/ejcn.2017.76

Punder, K. De, \& Pruimboom, L. (2015). Stress induces endotoxemia and low-grade inflammation by increasing barrier permeability. Frontiers in Immunology, 6(5), 1-12. https://doi.org/10.3389/fimmu.2015.00223

Ranadheera, C. S., Vidanarachchi, J. K., Rocha, R. S., Cruz, A. G., \& Ajlouni, S. (2017). Probiotic Delivery through Fermentation: Dairy vs . Non-Dairy Beverages. Fermentation, 3(67), 1-17. https://doi.org/10.3390/fermentation3040067

Riyanto, S., \& Muwarni, H. (2015). Yoghurt Kedelai Hitam (Black Soygurt) Dapat Menurunkan Kadar LDL Tikus Hiperkolesterolemia. Jurnal Gizi Dan Diatetik Indonesia, 3(1), 1-9. Retrieved from https://ejournal.almaata.ac.id/index .php/IJND/article/view/300

Sahin, I., Bilir, B., Ali, S., Sahin, K., \& Kucuk, O. (2019). Soy Isoflavones in Integrative Oncology: Increased Efficacy and Decreased Toxicity of Cancer Therapy. Integrated Cancer Therapies, 18, 1-11. https://doi.org/10.1177/1534735419835310

Sartang, M. M., Mazloomi, S. M., Tanideh, N., \& Zadeh, A. R. (2015). The Effects of Probiotic Soymilk Fortified with Omega-3 on Blood Glucose , Lipid Profile , Haematological and Oxidative Stress, and Inflammatory Parameters in 
Streptozotocin Nicotinamide-Induced Diabetic Rats. Journal of Diabetes Research, 2015, 1-9. Retrieved from https://www.hindawi.com/journals/jdr/2015/696372/

Serlahwaty, D., Syarmalina, \& Sari, N. (2015). Analısıs Kandungan Lemak dan Proteın Terhadap Kualıtas Soyghurt dengan Penambahan Susu Skım. Berkala Ilmiah Farmasi, 4(2), 35-42. Retrieved from http://journal.unair.ac.id/downloadfullpapers-bikf0c57c542542full.pdf

Susilawati, Y., Muhtadi, A., \& Moektiwardoyo, M. (2014). Aktivitas Antidiabetes Ekstrak Etanol Daun Iler (Plectranthus scutellariodes (L.)R.Br. Pada Tikus Galur Wistar Dengan Metode Induksi Aloksan. Farmaka, 14(2), 82-96. Retrieved from http://jurnal.unpad.ac.id/farmaka/article/view/9296

Uchitomi, R., Nakai, S., Matsuda, R., Onishi, T., Miura, S., Hatazawa, Y., \& Kamei, Y. (2019). Genistein, daidzein, and resveratrols stimulate PGC-1 $\beta$-mediated gene expression. Biochemistry and Biophysics Reports, 17(November 2018), 51-55. https://doi.org/10.1016/j.bbrep.2018.11.009

Utami, R., Sandi, N. H., Hasti, S., \& Delvia, S. (2015). Uji Aktivitas Antidiabetes Ekstrak Etanol dari Akar dan Batang Tumbuhan Sekunyit ( Fibraurea Tinctoria Lour ) Rahayu Utami , Nofri Hendri Sandi , Syil fi a Hasti dan Sutri Delvia. Jurnal Farmasi Indonesia, 7(4), 216-222. Retrieved from https://www.google.com/url?sa=t\&rct

$=\mathrm{j} \& \mathrm{q}=\&$ esrc $=\mathrm{s} \&$ source $=$ web\& $\mathrm{cd}=1 \& \mathrm{ved}=2$ ahUKEwi3r8L0w4DIAhWM7XMBH $\mathrm{dL}$ 4CcIQFjAAegQIARAC\&url=http\%3A\%2F\%2Fwww.jfionline.org\%2Findex.php\%2 Fjurnal\%2Farticle\%2Fdownload\%2F198\%2F158\&usg=AOvVaw0U9JWofBEGss O4G4ACQv3x

Veerichetty, V. (2018). Antidiabetic Potential of The Combination of Fermented Soy Milk and Flaxseed Milk in Alloxan-Induced Diabetic Rats. International Journal of Green Pharmacy, 12(3), 763-768. Retrieved from https://www.greenpharmacy .info/index. php/ijgp/article/view/2115

Wolever, T. M. (2017). Yogurt Is a Low-Glycemic Index Food. The Journal of Nutrition, 147(7), 1462S-1467S. https://doi.org/10.3945/jn.116.240770

Wu, H., Shang, H., \& Wu, J. (2015). Effect of ezetimibe on glycemic control: a systematic review and meta-analysis of randomized controlled trials. Endocrine, 60(2), 229-239. https://doi.org/10.1007/s12020-018-1541-4 